\title{
EXPERIMENTAL INVESTIGATIONS INTO THE HAEMAGGLUTINATING FACTOR IN BLOOD AND JOINT FLUID IN RHEUMATOID ARTHRITIS*
}

\author{
BY
}

\author{
NANNA SVARTZ \\ From the Medical Department of the Karolinska Hospital and the \\ King Gustaf V Research Institute, Stockholm, Sweden
}

Shortly after Rose, Ragan, Pearce, and Lipman (1948) had published their paper on the agglutination of sensitized sheep cells in rheumatoid arthritis, investigations were started at the King Gustaf V Research Institute into the haemagglutinating factor that induces the reaction. The first reports of our experiments, presented by Svartz and Schlossmann (1949) and Svartz (1951a, b; 1952), were mainly concerned with the importance of removing the heterophil haemagglutinins which almost invariably exist in human serum, before carrying out the principal reaction. Similar observations were published by Sulkin, Pike, and Coggeshall (1952). The first attempts to absorb heterophil haemagglutinins had been made by Meyer (1922). Schlossmann and I have obtained positive results with our type of modification of the sheep cell test in 85 to 90 per cent. of cases of rheumatoid arthritis (Schlossmann and Svartz, 1950). The test was considered positive when the titre was $1: 64$ or higher. The frequency of positive reactions varied somewhat from one period to another depending on the nature of the cases tested. The more cases of active rheumatoid arthritis are included in a series the higher will be the percentage of positive reactions. But purely technical factors also influence the results. The sheep cells must be fresh and the amboceptor suitable, and the results should be read on two occasions: first when the

* Presented at a Plenary Session of the IX International Congress of Rheumatology at Toronto in June, 1957. tubes are taken from the refrigerator and then after they have stood for 2 hours at room temperature.

Sensitization.-Like other investigators, we have tried inter alia to elucidate the significance of the sensitizing process. The most important question is whether it is necessary-as is generally done-to let the amboceptor serum exert its influence on the blood corpuscles for some time before the final reaction is carried out.

Table I shows that the order in which the ingredients are mixed makes no difference. The erythrocytes need not be subjected to a sensitizing procedure before being used for the reaction. The rheumatoid factor may be added to the blood corpuscles first and the anti-erythrocyte serum (amboceptor-serum) may be added last, or all three ingredients may be mixed simultaneously. This opens up a new view of the problem of sensitization, though it is still not clear what conclusions may be drawn from these observations.

Differentiation from Other Diseases.-After rheumatoid arthritis, disseminated lupus erythematosus yields the highest percentage of positive reactions (about 30 per cent. clearly positive as well as a number of slightly positive tests). Scleroderma apparently comes third in regard to the percentage of positive reactions obtained.

TABLE I

THREE MAIN CONSTITUENTS OF HAEMAGGLUTINATION TEST MIXED TOGETHER IN DIFFERENT ORDER

\begin{tabular}{l|c|c|c|c}
\hline \multicolumn{1}{c|}{ Method } & \multicolumn{2}{c}{ Order of Mixing } & Titre \\
\hline Routine & (1) Erythrocytes & (2) Amboceptor 2 hrs & $\begin{array}{c}\text { (3) Patient Serum con- } \\
\text { taining Rheumatoid } \\
\text { Factor }\end{array}$ & $1: 2,048$ \\
\hline $\begin{array}{c}\text { Amboceptor added 2 hrs after } \\
\text { Patient Serum }\end{array}$ & (1) Erythrocytes & (2) Rheumatoid Factor 2 hrs & (3) Amboceptor & $1: 2,048$ \\
\hline $\begin{array}{c}\text { Three Constituents Mixed To- } \\
\text { gether Simultaneously }\end{array}$ & (1) Erythrocytes & (2) Amboceptor + Rheumatoid Factor & $1: 2,048$ \\
\hline
\end{tabular}


We then questioned whether the haemagglutinating factors in rheumatoid arthritis and in these other diseases were identical or could be differentiated. If the latter were the case, more specific reactions for the various diseases could probably be obtained. The investigations of Waaler (1940) showed that the haemagglutinating factor accompanies the serum gamma-globulins; Schlossmann and I therefore tested various globulin fractionation methods, and we obtained illuminating results by fractionating with ammonium sulphate and also with $\mathrm{CO}_{2}$. The latter method demonstrated that the haemagglutinating substance invariably found in the blood of guinea-pigs behaves differently from the rheumatoid factor.

Precipitation in Cold.-This method brought the problem of specificity a good way nearer solution. Serum was diluted fourteen times with distilled water and then allowed to stand for $48 \mathrm{hrs}$ at $+4^{\circ} \mathrm{C}$. The remarkable fact was then demonstrated that the haemagglutinating factor in rheumatoid arthritis could be precipitated in cold, whereas the haemagglutinating factor in other diseases remained as a rule in the supernatant fluid (Svartz and Schlossmann, 1953a, b; 1955; 1957). Cold precipitation thus proved to be an excellent means of avoiding "non-specific" reactions in rheumatoid arthritis, and this method has now been adopted for testing in various other laboratories. The method has also been modified so that, instead of our procedure of precipitation, centrifugation, and washing, dialysis has been used at the same temperature as in our experiments (Lospalluto and Ziff, 1956; Ziff, Brown, Lospalluto, Badin, and McEwen, 1956).

We then tried precipitation in cold with disseminated lupus erythematosus and scleroderma (Svartz and Schlossmann, 1957). Only one out of thirty cases of lupus erythematosus showed a positive cold precipitate reaction (Table II). The diagnosis in this case is not yet quite clear, as L.E. cells have been found to be present; since Kievits, Goslings, and Schuit (1956), Goslings and Kievits (1957), and Olhagen (personal communication) found L.E. cells in rheumatoid arthritis, this may be a case of severe rheumatoid arthritis resembling lupus erythematosus.

Only two cases of scleroderma showed a positive haemagglutination reaction, but one of them also showed a positive cold precipitate reaction (Table III). Olhagen has recently found that this patient had severe arthritis resembling rheumatoid arthritis, and an $x$-ray examination of the joints also showed changes typical of rheumatoid arthritis. This case therefore seems to show a combination of rheumatoid arthritis with scleroderma.
TABLE II

AGGLUTINATION BY WHOLE SERUM AND COLD PRECIPITABLE FRACTIONS IN PATIENTS WITH DISSEMINATED LUPUS ERYTHEMATOSUS

\begin{tabular}{c|c|c|}
\hline \multirow{2}{*}{$\begin{array}{c}\text { Number of } \\
\text { Controlled Samples }\end{array}$} & \multicolumn{2}{|c|}{ Agglutination Titre } \\
\cline { 2 - 3 } & $\begin{array}{c}\text { Whole } \\
\text { Serum }\end{array}$ & $\begin{array}{c}\text { Cold Precipitable } \\
\text { Fraction }\end{array}$ \\
\hline 5 & $1: 16$ & 0 \\
7 & $1: 32$ & 0 \\
4 & $1: 64$ & 0 \\
2 & $1: 64$ & $1: 4$ \\
2 & $1: 128$ & 0 \\
2 & $1: 128$ & $1: 4$ \\
1 & $1: 256$ & 0 \\
1 & $1: 256$ & $1: 4$ \\
1 & $1: 256$ & $1: 256$ \\
1 & $1: 256$ & $1: 4$ \\
1 & $1: 512$ & $1: 8$ \\
\hline
\end{tabular}

TABLE III

HAEMAGGLUTINATION TEST IN SCLERODDRMA

\begin{tabular}{|c|c|c|}
\hline $\begin{array}{l}\text { Number of } \\
\text { Patients }\end{array}$ & $\begin{array}{l}\text { Whole } \\
\text { Serum }\end{array}$ & $\begin{array}{l}\text { Cold Precipitable } \\
\text { Fraction }\end{array}$ \\
\hline $\begin{array}{l}7 \\
1 \\
1 \\
1 \\
1 \\
1\end{array}$ & $\begin{array}{c}\text { Negative } \\
1: 8,192 \\
1: 128 \\
1: 256 \\
1: 512 \\
1: 1,024\end{array}$ & $\begin{array}{c}1: \overline{2,048} \\
\begin{array}{c}\text { Negative } \\
* \\
* \\
\end{array}\end{array}$ \\
\hline
\end{tabular}

* The test was performed before 1952 when the cold precipitaf reaction was not yet used.

The fact that the rheumatoid factor is precipitated in cold, whereas the haemagglutinating substances in lupus erythematosus, scleroderma, and other $\triangle$ diseases are not, indicates that different substances $\overrightarrow{\overrightarrow{0}}$ are involved. The difference may not be great, yet 3 it is wide enough for these substances to behave differently in cold fractionation.

Just as other biological reactions are not entirely specific for one disease only, cold precipitation is not entirely specific for rheumatoid arthritis. The $\frac{3}{3}$ diagnosis was not quite clear in the one case designated as lupus erythematosus and in the one case of $\frac{\circ}{3}$ scleroderma which gave a positive cold precipitation reaction. We have also observed weakly positive $\stackrel{\circ}{J}$ reactions in two cases of hepatitis, one case of $\frac{D}{O}$ myeloma, and a few cases of psoriasis.

Fractionation in cold is thus a first step towards N isolating the rheumatoid factor.

Zone Electrophoresis.-These experiments were $\mathrm{N}_{\mathrm{W}}$ conducted by the method of Carlson (1954) in a? special type of starch column; between 20 and 250 fractions were obtained. Fig. 1 (opposite) shows $\mathbb{\Phi}$ that only very small quantities of protein were found? in the cold precipitate except in the gamma area. $\frac{T}{3}$ 


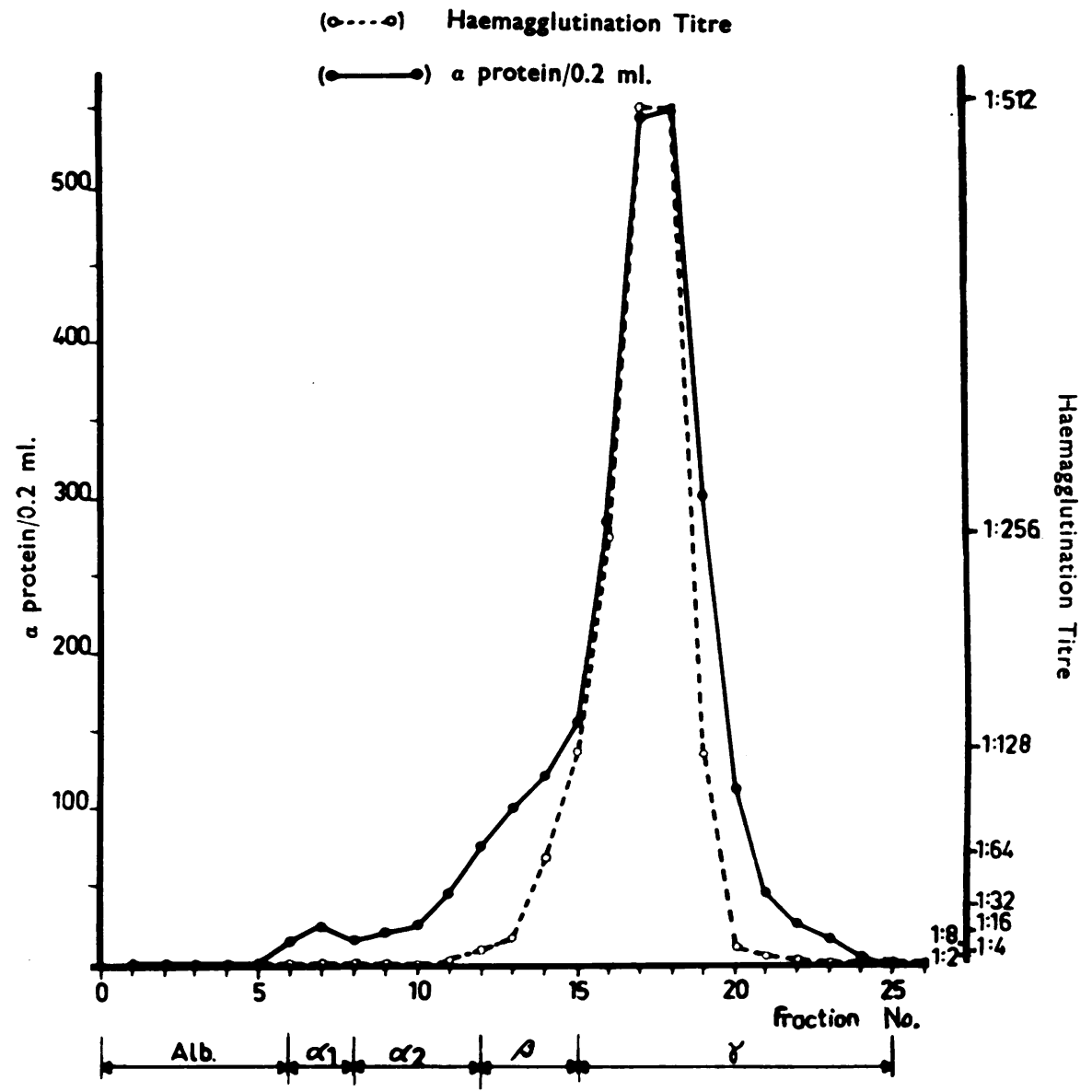

Fig. 1.-Zone electrophoresis on redissolved cold precipitate from rheumatoid arthritis serum (8-fold concentrated).

Thus, the haemagglutination factor was demonstrable in the gamma-globulin fraction and in that part of the beta area bordering on the gamma area. Minor quantities of globulins outside these fractions did not give rise to haemagglutination.

Ultra-Centrifugation.-Prof. Hugo Theorell gave permission to conduct ultra-centrifugation experiments at his Institute, and this process has been carried out on a number of cold precipitates from rheumatoid arthritis serum since January, 1957, with the assistance of A. Ehrenberg, an engineer at the Institute (Svartz, 1957). A top and a bottom fraction were obtained by analytical ultra-centrifugation. The results are shown in Table IV. The top fractions had a sedimentation constant of 6 to $6 \cdot 4$ Svedberg, the bottom fractions 19 to $20 \mathrm{~S}$. Thus, the bottom fraction contained macroglobulins. The molecular size was apparently about 1 million.
TABLE IV

ULTRA-CENTRIFUGATION (60,000 r.p.m. and 33 min.) OF COLD PRECIPITATE FROM RHEUMATOID ARTHRITIS SERUM

\begin{tabular}{|c|c|c|c|}
\hline $\begin{array}{c}\text { Cold } \\
\text { Precipitate }\end{array}$ & & $\begin{array}{l}\text { Sedimentation } \\
\text { Coefficient }\end{array}$ & $\begin{array}{c}\text { Haemagglutina- } \\
\text { tion }\end{array}$ \\
\hline $\begin{array}{l}\text { Fraction I (top) } \\
\text { Fraction II (bottom) }\end{array}$ & $\cdots$ & ${ }_{19}^{6 \cdot 4} \mathrm{~S}$ & $\begin{array}{l}\text { Negative } \\
\text { Positive }\end{array}$ \\
\hline $\begin{array}{l}\text { Fraction I (top) } \\
\text { Fraction II (bottom) }\end{array}$ & $\begin{array}{l}\cdots \\
\cdots\end{array}$ & ${ }_{19}^{6 \cdot 6} \mathrm{~S}$ & $\begin{array}{l}\text { Negative } \\
\text { Positive }\end{array}$ \\
\hline $\begin{array}{l}\text { Fraction I (top) } \\
\text { Fraction II (bottom) }\end{array}$ & 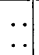 & $\begin{array}{lrr}\text { about } & 6 & S \\
\text { about } 20 & \text { S }\end{array}$ & $\begin{array}{l}\text { Negative } \\
\text { Positive }\end{array}$ \\
\hline
\end{tabular}

Haemagglutination tests were conducted on both the top and the bottom fractions, and the reaction was negative on the top fraction and strongly positive on the bottom fraction. This proved that the haemagglutinating factor was present in a fraction containing macroglobulins. 
Table $\mathrm{V}$ shows ultra-centrifugation performed twice on cold precipitate from the same rheumatoid arthritis serum, and the quantities of low and high molecular globulins. The percentage of macroglobulins in the bottom fractions was 42 to 44 per cent.

TABLE V

ULTRA-CENTRIFUGATION OF SAME COLD PRECIPITATE ON TWO DIFFERENT OCCASIONS

\begin{tabular}{|c|c|c|c|c|c|}
\hline Date & \multicolumn{2}{|l|}{$\begin{array}{c}\text { Cold } \\
\text { Precipitate }\end{array}$} & $\begin{array}{c}\text { c : a } 6 \cdot 6 \mathrm{~S} \\
\text { (mg./ml.) }\end{array}$ & $\begin{array}{l}\text { c : a } 22 \text { S } \\
\text { (mg./ml.) }\end{array}$ & $\begin{array}{c}\text { Haem- } \\
\text { agglutination } \\
\text { Reaction }\end{array}$ \\
\hline 29.1.57 & $\begin{array}{l}\text { Bottom } \\
\text { Top . . }\end{array}$ & $\begin{array}{l}\cdots \\
\cdots\end{array}$ & $\begin{array}{l}2 \cdot 3 \\
4 \cdot 3 \\
0 \cdot 8\end{array}$ & $\begin{array}{l}1 \cdot 4 \\
3 \cdot 4 \\
0\end{array}$ & $\begin{array}{l}\text { Positive } \\
\text { Positive } \\
\text { Negative }\end{array}$ \\
\hline \multirow[b]{2}{*}{5.2 .57} & \multirow[b]{2}{*}{$\begin{array}{l}\text { Bottom } \\
\text { Top .. }\end{array}$} & & $\begin{array}{l}\mathrm{c}: \text { a } 6.4 \mathrm{~S} \\
(\mathrm{mg} . / \mathrm{ml} .)\end{array}$ & $\begin{array}{l}c: \text { a } 20 \mathrm{~S} \\
\text { (mg./ml.) }\end{array}$ & $\begin{array}{l}\text { Haem- } \\
\text { agglutination } \\
\text { Reaction }\end{array}$ \\
\hline & & $\begin{array}{l}\cdots \\
\cdots\end{array}$ & $\begin{array}{l}2 \cdot 3 \\
4 \cdot 1 \\
0 \cdot 7\end{array}$ & $\begin{array}{l}1 \cdot 4 \\
2 \cdot 9 \\
0\end{array}$ & $\begin{array}{l}\text { Positive } \\
\text { Positive } \\
\text { Negative }\end{array}$ \\
\hline
\end{tabular}

Zone-electrophoresis was then carried out on the macroglobulin fraction (Fig. 2). The haemagglutinating factor was found exclusively in the gamma fraction; it appeared that the factor was still not isolated-which indeed was hardly to be expected.

Preparative ultra-centrifugation was also tried (Table VI). The bottom fractions were afterwards run in separation cells. Sedimentation constants from 19 to $25 \mathrm{~S}$ could be observed in these fractions.
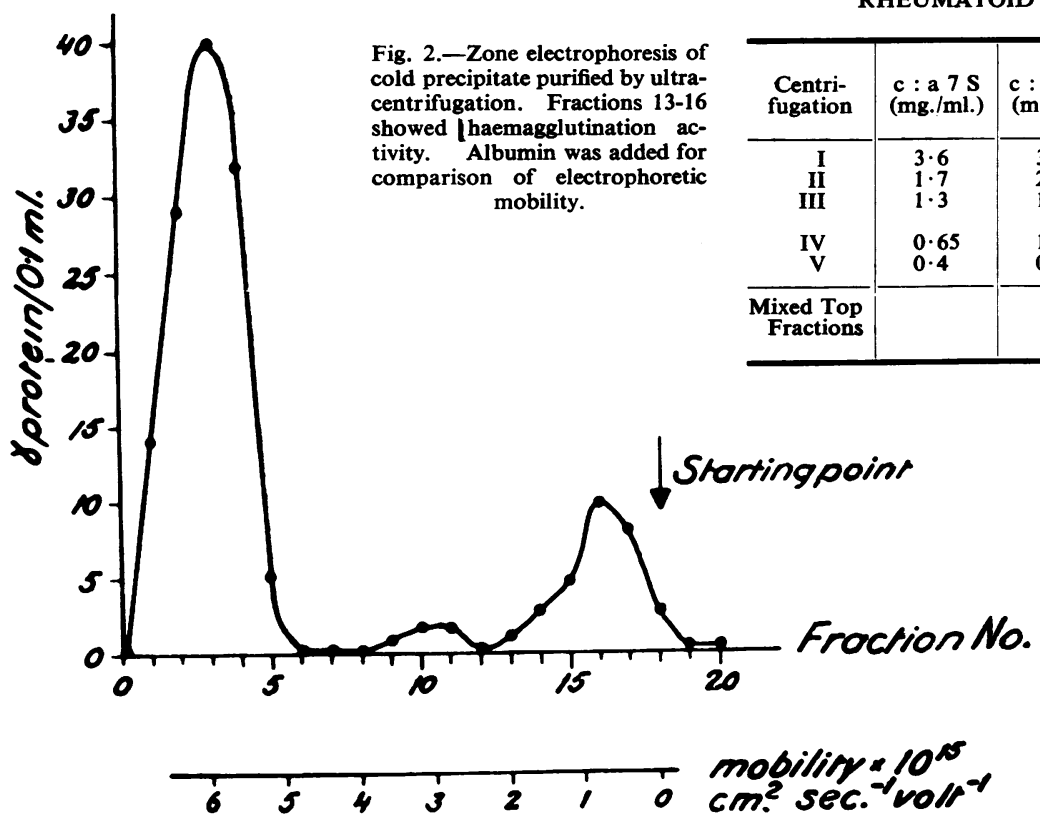
centrifugation. ched haemagglutination acAlbumin was added for of electrophoretic
It usually happened that the bottom fractions were somewhat turbid. The turbidity was not dissolve by dilution, but had to be removed by ordinary

TABLE VI

PREPARATIVE ULTRA-CENTRIFUGATION OF COLD PRECIPITATE FROM RHEUMATOID ARTHRITIS SERUM (497)

\begin{tabular}{|c|c|c|c|}
\hline \multicolumn{2}{|c|}{ Fractions Numbered from Bottom } & \multicolumn{2}{|c|}{ Haemagglutination Titre } \\
\hline \multicolumn{2}{|c|}{$\begin{array}{l}1 \\
2 \\
3 \\
4 \\
5 \text { (top) }\end{array}$} & \multicolumn{2}{|c|}{$\begin{array}{l:l}1 & : 512 \\
1 & : 1,024 \\
1 & : 1,024 \\
1 & 1,024 \\
1 & : 16\end{array}$} \\
\hline \multicolumn{4}{|c|}{ Number 1 after Run in Separation Cell } \\
\hline $\begin{array}{c}\text { Cold } \\
\text { Precipitate }\end{array}$ & $\begin{array}{c}\text { Sedimentation } \\
\text { Constant }\end{array}$ & $\mathbf{m g} . / \mathrm{ml}$. & $\begin{array}{c}\text { Haemagglutin } \\
\text { tion Titre }\end{array}$ \\
\hline $\begin{array}{l}\text { Bottom .. } \\
\text { Top } \quad \ldots\end{array}$ & $19 \mathrm{~S}+25 \mathrm{~S}$ & $\begin{array}{l}0.58 \\
0.85\end{array}$ & $\begin{array}{l}1: 256 \\
1: 16\end{array}$ \\
\hline
\end{tabular}

Muller-Eberhard, Kunkel, and Franklin $(195 \ddot{\phi}$ have recently conducted experiments of a simila $\$$ nature to those just described.

By means of serial ultra-centrifugation, experio ments were made further to eliminate the low molecular globulins (Table VII).

TABLE VII

REPEATED ANALYTICAL ULTRA-CENTRIFUGATION OF REDISSOLVED COLD PRECIPITATE FROM RHEUMATOID ARTHRITIS SERUM (513)

\begin{tabular}{|c|c|c|c|c|}
\hline $\begin{array}{l}\text { III } \\
\text { IV } \\
\text { V }\end{array}$ & $\begin{array}{l}1 \cdot 3 \\
0 \cdot 65 \\
0 \cdot 4\end{array}$ & $\begin{array}{l}1 \cdot 0 \\
1 \cdot 15 \\
0 \cdot 8\end{array}$ & $\begin{array}{l}0 \cdot 8 \\
1 \cdot 8 \\
2\end{array}$ & $\begin{array}{c}1: 64 \\
\text { (precipitated) } \\
1: 128 \\
1: 64\end{array}$ \\
\hline $\begin{array}{r}\text { Mixed Top } \\
\text { Fractions }\end{array}$ & & & & $1: 32$ \\
\hline
\end{tabular}

The fraction from the third centrifugation showe a sudden decrease in haem? agglutination titre. There were signs of precipitatiof which could not be diso solved on the walls of the separation cell. It is obvious that a great dea of the haemagglutinating factor had followed the precipitate. We also noted 
another difference between the second and third bottom fractions; there were two peaks at the level of 19 to 25 S in Fraction II, but in Fraction III the globulins with the higher sedimentation constant had disappeared.

As to the evaluation of the different sedimentation constants in human sera, the experience of Wallenius, Trautman, Kunkel, and Franklin (1957) has been very useful.

Chromatography.-Paper chromatography on redissolved cold precipitate proved unsuitable, and other types of chromatography were tried, in collaboration with Dr. L. Carlson.
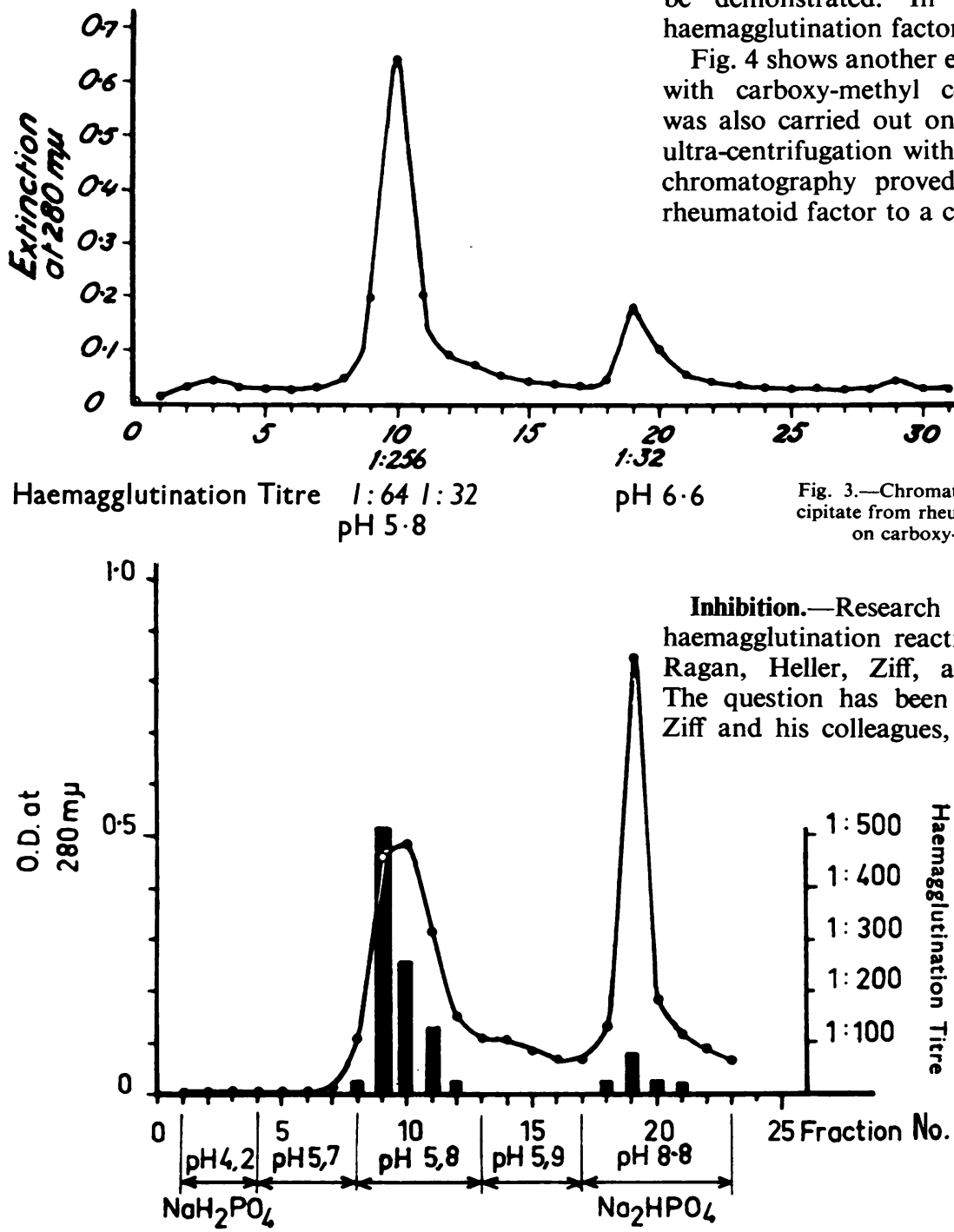

Fig. 4.-Chromatography of cold precipitate on carboxy-methyl cellulose.
Chromatography with a phosphate column yielded no results of importance.

Chromatography with carboxy-methyl cellulose by the method of Peterson and Sober (1956) proved very valuable. A glass cylinder was filled with carboxy-methyl cellulose, which is a cation exchanger, as in other forms of column chromatography. Cold precipitate from serum containing the rheumatoid factor was dissolved in phosphate buffers with different $\mathrm{pH}$ and allowed to filter through the carboxy-methyl cellulose (Fig. 3). In this way, 30 fractions were obtained, and in three of these the existence of a strong haemagglutinating factor could be demonstrated. In another peak, traces of haemagglutination factor were found.

Fig. 4 shows another example of chromatography with carboxy-methyl cellulose. Chromatography was also carried out on the bottom fraction from ultra-centrifugation with similar results. Repeated chromatography proved capable of isolating the rheumatoid factor to a certain extent. 
normally contains an inhibitor. By injecting rabbits with rheumatoid arthritis serum from which heterophil agglutinins had been removed, we were able to produce a factor which neutralized the rheumatoid factor at a high titre. Also the anti-rabbit serum was previously absorbed with normal red cells. These experiments show that the rheumatoid factor may act as an antigen.

We have also carried out experiments designed to inhibit the haemagglutination reaction by means of various drugs, including cortisone, gold, aspirin, and penicillin. They did not cause any inhibition, but the sulpha drugs were found to have the strongest effect in vitro (Table VIII). This should also be tried in vivo, but so far it has only been possible to show the effect with a concentration that can never be induced in a human being.

TABLE VIII

SULPHONAMIDE COMPOUNDS PRODUCING COMPLETE INHIBITION OF HAEMAGGLUTINATION REACTION

\begin{tabular}{|c|c|}
\hline Types of Compounds & $\begin{array}{l}\text { Lowest Concentration } \\
\text { showing Inhibition }\end{array}$ \\
\hline 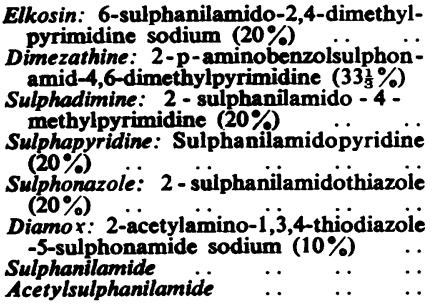 & $\begin{array}{l}1 \cdot 20: 100 \\
0 \cdot 52: 100 \\
1 \cdot 20: 100 \\
1 \cdot 20: 100 \\
0 \cdot 62: 100 \\
0 \cdot 31: 100 \\
0 \cdot 63: 100 \\
\text { No Inhibition }\end{array}$ \\
\hline
\end{tabular}

In collaboration with $L$. O. Plantin and the Pharmacia Drug Company, attempts have been made to discover which radicals are necessary for the inhibiting activity of the sulpha drugs. Table VIII shows that sulphanilamide exerts a pronounced inhibiting effect on the haemagglutination reaction. If a hydrogen of the amino group is replaced by acetyl, the inhibitory power is lost. Our investigations in this field are being continued.

\section{Summary}

The haemagglutination of pre-treated red cells can be produced by serum from different diseases. These haemagglutinating substances are not identical - that in lupus erythematosus differing, for example, from that in rheumatoid arthritis.

Svartz and Schlossmann (1953a, b; 1955) showed that the haemagglutination factor was precipitable in cold in rheumatoid arthritis, but not-or only very seldom -in other diseases, such as disseminated lupus erythematosus and scleroderma.

Various attempts were made to isolate the cold precipitable factor in rheumatoid arthritis, by zone- electrophoresis, ultra-centrifugation, and chromatography with carboxy-methyl cellulose.

By using zone-electrophoresis of cold precipitate, 20-25 protein fractions were obtained. The rheumatoid factor was found to be present mainly in the gamma-globulin area.

Ultra-centrifugation of cold precipitate from음 rheumatoid arthritis serum demonstrated that the $\frac{\bar{c}}{2}$ rheumatoid factor was associated with a macro- $\mathbb{\otimes}$ globulin fraction showing a sedimentation constant of 19-25 Svedberg. The fractions containing low- ${ }^{\infty}$ molecular globulins did not evoke haemagglutina- $\vec{\circ}$ tion. Serial centrifugation in ultra-centrifuge was $\vec{\omega}$ also performed.

The best method of isolating the rheumatoid factor so far attained is precipitation in cold followed by alternating ultra-centrifugation and chromato- $\vec{a}$ graphy with carboxyl-methyl cellulose.

\section{REFERENCES}

Carlson, L. A. (1954). Acta chem. scand., 8, 510.

Goslings, J., and Kievits, J. H. (1957). Annals of the Rheumatic Diseases, 16, 385

Kievits, J. H., Goslings, J., and Schuit, H. R. E. (1956. In "Contemporary Rheumatology", "Proc. III Europ. Rheum. Cong., The Hague-Scheveningen, 1955", ed. J. Goslings and H. van® Swaay, p. 173. Elsevier, Amsterdam.

Lospalluto, J., and Ziff, M. (1956). Annals of the Rheumatic Diseases,

Meyer, K. (1922). Z. Immun.-Forsch. (Orig.), 34, 229.

Müller-Eberhard, H. J., Kunkel, H. G., and Franklin, E. C. (1950). Proc. Soc. exp. Biol. (N.Y.), 93, 146

Olhagen, B. Personal communication.

Peterson, E., and Sober, H. (1956). J. Amer. chem. Soc., 78, 751 .

Rose, H. M., Ragan, C., Pearce, E., and Lipman, M. O. (19). Proc. Soc. exp. Biol. (N. Y.), 68, 1.

Sulkin, S. E., Pike, R. M., and Coggeshall, H. C. (1952). Ins "Rheumatic Diseases", based on "Proc. VII Int. Congr.? Rheum. Dis., New Yórk, 1949", p. 360. Saunders, Phila-O Rheum.

Svartz, N. (1951a). Acta med. scand., Suppl. 259, p. 18. (1951b). Nord. Med., 46, 1199.

(1952). In "Rheumatic Diseases", based on "Proc. VII Int Congr. Rheum. Dis., New York. 1949", p. 360. Saunders, Philadelphia.

(1957). Acta med. scand., 158, 163.

and Schlossmann, K. (1949). Nord. Med., 42, 1390.

- and Schlossmann, $\mathbf{K}$. (1950). Annals of the Rheumatic Diseases, 9, 1.

- - (1950). Annals of the Rheumatic Diseases,

,-- (1953b). Acta med. scand., 145, 216.

- _ (1955). Annals of the Rheumatic Diseases, 14, 191.

- - (1956). Acta med. scand., 155, 131.

- (1957). Annals of the Rheumatic Diseases, 16, 73.

Waaler, E. (1940). Acta path. microbiol. scand., 17, 172 .'

Wallenius, G., Trautman, R., Kunkel, H. G., and Franklin, E. G (1957). J. biol. Chem., 225, 253.

Winblad, S. (1952). Acta med. scand., 142, 450, 458.

Ziff, M., Brown, P., Lospalluto, J., Badin, J., and McEwen, C. (1656) Amer. J. Med., $20,500$.

Etudes expérimentales du facteur hémagglutinant dansp le sang et le liquide synovial dans l'arthrite rhumatismaleo RÉSUMÉ

Des sérums de différentes maladies peuvent produire l'hémagglutination des globules rouges préparés. Ces substances hémagglutinantes ne sont pas identiquescelles de lupus érythémateux étant différentes, par exemple, de celles de l'arthrite rhumatismale.

Svartz et Schlossmann (1953a, b; 1955) ont montré que le facteur hémagglutinant était précipitable paf́ le froid dans l'arthrite rhumatismale, mais pas-ous seulement très rarement-dans les autres maladies, telles que le lupus érythémateux disséminé et la sclérodermie. 
Des tentatives variées ont été faites pour isoler le facteur précipitable au froid dans l'arthrite rhumatismale, par zones d'électrophorèse, ultra-centrifugation et chromatographie à l'aide de la carboxy-methyl-cellulose.

L'électrophorèse du précipité à froid donna de 20 à 25 fractions protéiques. Le facteur rhumatismal se révéla présent surtout dans la zone de globuline gamma.

L'ultra-centrifugation du précipité à froid de sérum provenant d'arthrite rhumatismale démontra que le facteur rhumatismal était associé à une fraction de macroglobuline ayant une constante de sédimentation de 19 à 25 Svedberg. Les fractions contenant des globulines à poids moléculaire bas ne provoquaient pas d'hémagglutination. La centrifugation en série en ultracentrifugeuse fut aussi effectuée.

Jusqu'à présent, la meilleure méthode d'isoler le facteur rhumatismal est la précipitation à froid, suivie par l'ultra-centrifugation et la chromatographie à l'aide de la carboxy-méthyl-cellulose, alternantes.

Investigaciones experimentales del factor hemaglutinante en la sangre y el líquido articular en la artritis reumatoide

\section{Sumario}

Sueros de enfermedades diferentes pueden producir la hemaglutinación de eritrocitos preparados. Estas substancias hemaglutinantes no son idénticas-las del lupus eritematoso siendo, por ejemplo, diferentes de las de la artritis reumatoide.

Svartz y Schlossmann (1953a, b; 1955) demostraron que el factor hemaglutinante fué precipitable por el frío en la artritis reumatoide, pero que no lo fué-o sólo muy raramente - en otras enfermedades, como el lupus eritematoso diseminado y esclerodermia.

Se hicieron varias tentativas para aislar el factor precipitable por el frío en la artritis reumatoide, por zonas de electroforesis, ultra-centrifugación y cromatografia con carboxi-metil-celulosa.

La electroforesis del precipitado frío dió de 20 a 25 fracciones proteínicas. El factor reumático fué presente principalmente en la zona de la globulina gama.

La ultra-centrifugación del precipitado frío del suero procedente de sujetos con artritis reumatoide mostró que el factor reumático estuve asociado a una fracción de macroglobulina con una constante de sedimentación de 19-25 Svedberg. Las fracciones conteniendo globulinas de peso molecular bajo no provocaban hemaglutinación. Se procedió también a la centrifugación en serie en ultra-centrifuga.

El mejor método que se conoce hasta ahora para aislar el factor reumático es la precipitación por el frío, seguida de ultra-centrifugación y de cromatografia con carboxi-metil-celulosa, alternantes. 